\title{
COMPARISON OF GLASS FIBER REINFORCED CONCRETE \& GEOPOLYMER CONCRETE WITH GLASS FIBER REINFORCEMENT
}

\author{
Shrikant Harle ${ }^{1}$, Sarang Dhawade ${ }^{2}$ \\ ${ }^{1,2}$ Department of Civil Engineering, Ram Meghe College of Engineering, Amravati (M.S.)
}

\begin{abstract}
In the world most commonly used as well as durable material is concrete. In the field of concrete technology, glass fiber reinforced concrete (GFRC) is the recently introduced material. GFRC has many advantages such as light weight material, steel reinforcement corrosion free and structural deterioration free. So, these are the reason the researchers all over the globe are attempting to develop high performance concrete with the use of glass fibers as well as admixtures. While the combination of fly ash, alkaline liquids, fine and coarse aggregate and glass fibers resulted in the product called as Glass Fiber Reinforced Geopolymer Concrete (GFRGC). This product has many advantages such as high early strength, corrosion and sulphate resistance and low shrinkage. The present work has compared the compressive strength, split tensile strength and flexural strength for GFRC and GFRGC. From this comparison it is observed that except for the flexural strength the normal concrete with the addition of glass fibers shown good results as compared to the geopolymer concrete with the addition of glass fibers. This work is only an accumulation of information about GFRC and the research work which is already carried out by other researchers.
\end{abstract}

Key Words: GFRC, GC, Geopolymer Concrete, Glass Fiber Reinforced Concrete, Glass Fiber Reinforcement

\section{INTRODUCTION}

The production rate of concrete as well as the growth rate of infrastructure highlight and reflect the economic strength and the degree of civilization. It is well known that concrete is one of the most far used construction material all over the globe [4]. Ordinary Portland Cement (OPC) becomes an important material all over the globe in the production of concrete which acts its binder to bind all the aggregate together. However, the utilization of cement causes pollution to the environment and reduction of raw material. The manufacturing of OPC requires the burning of large quantities of fuel as well as decomposition of limestone, which has resulted in significant amount emissions of $\mathrm{CO}_{2}$ [5].

The performance concrete is usually determined by its strength and durability. By reducing the water content, increasing the binder and aggregate content, using a well graded aggregate and using a good curing method and better compaction can be resulted in good quality of concrete. Further it was observed that the strength \& durability of concrete are influenced by the amount of size and type of pores [6].

\section{REVIEW OF LITERATURE}

The experimental investigation [1] was carried out on the alkali resistant (AR) glass fibers and studied the effect on compressive, tensile strength, split tensile and flexural strength on M20, M30, M40 and M50 grades of concrete. From the experimental results it was observed that percentage increase of compressive strength of various concrete grades of glass fiber concrete mixes compared with 28 days compressive strength to be from 20 to $25 \%$. As well as reduction in bleeding observed by addition of glass fibers in the glass fiber concrete mixes.

Concrete is the most widely used construction material all over the world and has very good as well as wide properties like high compressive strength, stiffness and durability under usual environmental factors. Normally reinforcement consists of continuous deformed steel bars or pre-stressing tendons. The study [2] was carried out and it was observed that strength and durability of concrete can be changed by making appropriate changes in its ingredients like cementitious material, aggregate and water by adding some special ingredients. Therefore concrete can be considered as a very suitable material for a wide range of application.

The experimental study [3] was conducted to study the mechanical properties of Geo Polymer Cement Concrete (GPCC) which contained $90 \%$ fly ash, $10 \%$ OPC, alkaline liquids as well as glass fibers in the percentage of $0.01 \%$, $0.02 \%$ and $0.03 \%$ by volume of concrete and the ratio of alkaline liquid to fly ash was 0.4 . The experiment included replacement of $10 \%$ of fly ash by OPC in the mix resulted in an enhanced $73 \%$ compressive strength, $128 \%$ split tensile strength and $17 \%$ flexural strength as compared to GPC mix. Also the replacement of $10 \%$ fly ash by OPC in the GPC mix eliminates delay in setting time and necessity of heat curing to gain strength which resulted in GPCC mix.

The study [9] was made to determine the mechanical properties of Geopolymer concrete composites (GPCC), which contains fly ash, alkaline liquids and glass fibers. The 
ratio for alkaline liquids to fly ash was fixed as 0.4 and in the experiment they replaced $100 \%$ ordinary Portland cement with fly ash. The addition of glass fibers made to the mix with $0.01 \%, 0.02 \%$ and $0.03 \%$. From the experiments performed it was observed that the geopolymer concrete composite had relatively higher strength in one day short curing time than the geopolymer concrete and ordinary Portland cement.

\section{RESULTS AND COMPARISON}

The comparison is done for adding varying amount of glass fibers in normal concrete and geopolymer concrete with zero percent fiber with the same material. The results of the compressive strength, flexural strength and split tensile strength are as presented in the following table.

Table 1: Comparison of Compressive strength

\begin{tabular}{|c|l|l|l|l|l|}
\hline Author & types of concrete & $\begin{array}{l}\text { grade of } \\
\text { concrete }\end{array}$ & no of days & \multicolumn{2}{l|}{ compressive strength } \\
\cline { 2 - 6 } & $\begin{array}{l}\text { with gf } \\
(\mathrm{MPa})\end{array}$ & $\begin{array}{l}\text { wihtout gf } \\
(\mathrm{MPa})\end{array}$ \\
\hline $\begin{array}{l}\text { Yogesh murthy, et al } \\
(2012)\end{array}$ & $\begin{array}{l}\text { Normal Concrete with waste } \\
\text { glass fiber (replacement of } \\
\text { aggregate) }\end{array}$ & M30 & 28 & $38.22(0.5 \%)$ & 38 \\
\hline $\begin{array}{l}\text { Chandramouli K, et al } \\
(2010)\end{array}$ & $\begin{array}{l}\text { Normal Concrete with AR glass } \\
\text { fiber (addition) }\end{array}$ & M30 & 28 & $48.56(0.03$ & 41.5 \\
\hline $\begin{array}{c}\text { Satish Kumar, et al } \\
(2012)\end{array}$ & $\begin{array}{l}\text { Geopolymer Concrete (100\% } \\
\text { replacement of OPC) }\end{array}$ & ----- & 28 & $\begin{array}{l}27.58 \\
(0.03 \%)\end{array}$ & 24.26 \\
\hline K. Vijay, et al (2012) & $\begin{array}{l}\text { Geopolymer Concrete (100\% } \\
\text { replacement of OPC) }\end{array}$ & ----- & 28 & $\begin{array}{l}25.87 \\
(0.03 \%)\end{array}$ & 28.49 \\
\hline
\end{tabular}

Table 2: Comparison of Flexural strength

\begin{tabular}{|c|c|c|c|c|c|}
\hline \multirow[t]{2}{*}{ Author } & \multirow[t]{2}{*}{ types of concrete } & \multirow{2}{*}{$\begin{array}{l}\text { grade of } \\
\text { concrete }\end{array}$} & \multirow[t]{2}{*}{ no of days } & \multicolumn{2}{|c|}{ Flexural strength } \\
\hline & & & & $\begin{array}{l}\text { with gf } \\
(\mathrm{MPa})\end{array}$ & $\begin{array}{l}\text { wihtout gf } \\
\text { (MPa) }\end{array}$ \\
\hline $\begin{array}{l}\text { Yogesh murthy, et al } \\
(2012)\end{array}$ & $\begin{array}{l}\text { Normal Concrete with waste } \\
\text { glass fiber (replacement of } \\
\text { aggregate) }\end{array}$ & M30 & 28 & $4.5 \quad(0.5 \%)$ & 4.1 \\
\hline $\begin{array}{l}\text { Chandramouli K, et al } \\
\text { (2010) }\end{array}$ & $\begin{array}{l}\text { Normal Concrete with AR glass } \\
\text { fiber (addition) }\end{array}$ & M30 & 28 & $4.78(0.03 \%)$ & 4.12 \\
\hline K. Vijay, et al (2012) & $\begin{array}{l}\text { Geopolymer Concrete }(100 \% \\
\text { replacement of OPC) }\end{array}$ & ----- & 28 & $5.31(0.03 \%)$ & 5.4 \\
\hline
\end{tabular}

Table 3: Comparison of Split Tensile strength

\begin{tabular}{|c|l|l|l|l|l|}
\hline Author & types of concrete & grade of concrete & no of days & \multicolumn{2}{l|}{ Split Tensile strength } \\
\cline { 2 - 6 } & & & $\begin{array}{l}\text { with gf } \\
(\mathrm{MPa})\end{array}$ & $\begin{array}{l}\text { wihtout gf } \\
(\mathrm{MPa})\end{array}$ \\
\hline $\begin{array}{l}\text { Chandramouli K, et al } \\
(2010)\end{array}$ & $\begin{array}{l}\text { Normal Concrete with AR glass } \\
\text { fiber (addition) }\end{array}$ & M20 & 28 & $4.2(0.03 \%)$ & 3.62 \\
\hline $\begin{array}{c}\text { Satish Kumar, et al } \\
(2012)\end{array}$ & $\begin{array}{l}\text { Geopolymer Concrete (100\% } \\
\text { replacement of OPC) }\end{array}$ & ------ & 28 & $2.33(0.03 \%)$ & 1.93 \\
\hline K. Vijay, et al (2012) & $\begin{array}{l}\text { Geopolymer Concrete (100\% } \\
\text { replacement of OPC) }\end{array}$ & ---- & 28 & $1.83(0.03 \%)$ & 3.02 \\
\hline
\end{tabular}




\section{CONCLUSION}

From the above results and comparison following point are observed:

- The compressive strength is found to be much more for normal concrete with the addition of glass fibers as compared to the geopolymer concrete with the addition of glass fibers.

- The flexural strength for geopolymer concrete with the addition of glass fibers found to be more as compared to the normal concrete with the addition of glass fibers.

- Split tensile strength is found to be more for normal concrete with the addition of glass fibers as compared to the geopolymer concrete with the addition of glass fibers.

\section{REFERENCES}

[1]. Chandramouli K, Seshadri Sekhar T, Sravana P, Pannirselvam N and Srinivasa Rao P (2010), Strength properties of glass fiber concrete, ARPN journal of Engineering and Applied sciences, vol. 5, no. 4.

[2]. Dr. P. Srinivasa Rao, Chandra Mouli K and Dr. T. Seshadri Sekhar (2012), Durability studies on glass fiber reinforced concrete, journal of civil engineering science: An international journal, vol 1 no 1-2, pp 37-42.

[3]. K. Vijai, R. Kumutha and B.G. Vishnuram (2012), Properties of glass fiber reinforced geopolymer concrete composites, Asian journal of civil engineering (Building and housing), vol 13, no 4, pages 511-520.

[4]. M. Fareed Ahmed, M. Fadhil Nuruddin and Nasir Shafiq (2011), Compressive strength and workability characteristics of low calcium fly ash based self compacting geopolymer concrete, International journal of civil and environmental engineering, vol 3, issue 2, pp 72-78.

[5]. Mohd. Mustafa Al Bakri, H. Mohammed, H. Kamarudin, I. Khairul Niza and Y. zarina (2011), Review on fly ash based geopolymer concrete without Portland cement, Journal of Engineering and technology research, vol 3, issue 1, pp 1-4.

[6]. Monita Olivia and Hamid R. Nikraz (2011), Strength and water penetrability of fly ash geopolymer concrete, ARPN journal of engineering and applied sciences, Vol 6, issue 7, pp 70-78.

[7]. M. I. Abdul Aleem and P. D. Arumairaj (2012), Geopolymer concrete - A review, International journal of engineering sciences \& emerging technologies, vol 1 , issue 2, pp 118-122.

[8]. Sandeep G. Sawant, A. B. Sawant and M. B. Kumthekar (2013), Strengthening of R.C.C. beam-using different glass fibers, International journal of inventive engineering and sciences, vol 1, issue 2.

[9]. Sathish Kumar V, Blessen Skariah Thomas and Alex Christopher (2012), An experimental study on the properties of glass fiber reinforced geopolymer concrete, International journal of engineering research and application, vol 2, issue 6 , pp 722-726.
[10]. Yogesh Iyer Murthy, Apporv Sharda and Gourav Jain (2012), Performance of glass fiber reinforced concrete, International journal of engineering and innovative technology, vol 1, Issue 6. 